Surv Ophthalmol. 2007 ; 52(2): 180-195. doi:10.1016/j.survophthal.2006.12.003.

\title{
Obesity and Eye Diseases
}

\author{
Ning Cheung, MBBS ${ }^{1,2}$ and Tien Y. Wong, FRANCO, FRCSE, PhD ${ }^{1,3}$ \\ 1 Centre for Eye Research Australia, University of Melbourne, Victoria, Australia
}

2Royal Melbourne Hospital, Victoria, Australia

3Singapore Eye Research Institute, National University of Singapore, Singapore

\begin{abstract}
The prevalence of obesity has reached epidemic proportions in many countries. While its impact on overall health is well documented, less is known about the ocular manifestations of obesity. Amongst different eye diseases, obesity has been linked with age-related cataract, glaucoma, age-related maculopathy, and diabetic retinopathy. Numerous population-based and prospective studies support an association between obesity and risk of age-related cataract. However, the nature and strength of these associations, particularly with the different cataract subtypes, remains to be determined. There is strong evidence that obesity is associated with elevated intraocular pressure, but there is no convincing data to support a more direct association between obesity and glaucomatous optic neuropathy. Studies to date have not found a consistent pattern of association between obesity and risk of age-related maculopathy or diabetic retinopathy. Thus, while obesity may be a risk factor for many ocular conditions, the present literature is inadequate to establish any convincing associations. Furthermore, whether weight loss reduces the risk of eye diseases remains unresolved. Because of the potential public health impact of obesity, there is a greater need to understand its ocular effects.
\end{abstract}

\section{Keywords}

age-related maculopathy; body mass index; cataract; eye disease; glaucoma; obesity; pseudotumor celebri; retinal artery occlusion; retinal vein occlusion; retinopathy

\section{Introduction}

Obesity is a major public health problem, with prevalence increasing at staggering rates in many countries. $50,51,54,55,77,85,97,98$ The World Health Organization (WHO) defines obesity as a body mass index (BMI) of $30 \mathrm{~kg} / \mathrm{m}^{1}$ or greater, and overweight as individuals whose BMI falls between $25 \mathrm{~kg} / \mathrm{m}^{1}$ and $29.9 \mathrm{~kg} / \mathrm{m}^{1}$. (World Health Organization. Controlling the global obesity epidemic. Geneva: World Health Organization; 2002) Different classifications are used for some specific populations, such as the Asians and the children. In Asian populations, it has been proposed that a BMI of $25 \mathrm{~kg} / \mathrm{m}^{1}$ or greater should be classified

Correspondence to: Tien Y. Wong, MD, PhD, Retinal Vascular Imaging Centre, Centre for Eye Research Australia, University of Melbourne, 32 Gisborne Street, East Melbourne 3002, AUSTRALIA, Tel: +61 399298352 / Fax: +61 396623859 / Email: E-mail: twong@unimelb.edu.au.

PUBLIC HEALTH AND THE EYE

JOHANNA SEDDON AND DONALD FONG, EDITORS

Publisher's Disclaimer: This is a PDF file of an unedited manuscript that has been accepted for publication. As a service to our customers we are providing this early version of the manuscript. The manuscript will undergo copyediting, typesetting, and review of the resulting proof before it is published in its final citable form. Please note that during the production process errors may be discovered which could affect the content, and all legal disclaimers that apply to the journal pertain. 
as obesity. ${ }^{98}$ In children, BMI is classified according to percentiles for age and sex, and children with BMI higher than 95th percentiles for age and sex may be considered as overweight. ${ }^{30,39,133}$

Obesity affects a wide spectrum of age groups, from the young 39,133 to the elderly. ${ }^{104}$ In the United States, the prevalence of obesity is $30 \%$ in $1999-2000,{ }^{51}$ with $65 \%$ of adults, and 10 to $15 \%$ of children and adolescents categorized as overweight or obese. ${ }^{77,81}$ The current International Obesity Task Force estimates suggest at least 1.1 billion people are overweight worldwide, and 312 million of them are obese (World Health Organization/International Associatio: redefining obesity and its treatment. Available at:http://www.idi.org.au/obesity_report.htm).

The medical consequences of obesity are numerous. It is an established risk factor for many systemic diseases including coronary heart disease, type 2 diabetes mellitus, hypertension, stroke, dyslipidemia, osteoarthritis, and sleep apnea. $43,69,77,123,155$ Obesity has also been associated with certain types of cancers. 12,20 One study estimated that obesity is responsible for approximately $40 \%$ of endometrial cancers, $25 \%$ of renal cancers, and $10 \%$ each of colonic and breast cancers. ${ }^{12}$ Other obesity-associated co-morbidities include polycystic ovary syndrome, fatty liver as well as depression secondary to social stigmatization and discrimination. 123

The impact of obesity on health is widespread, and the deleterious effects of obesity on the cardiovascular and metabolic systems are well known. ${ }^{77}$ Less well documented, however, are the potential ocular effects of obesity. Obesity has recently been reported to be negatively associated with visual acuity, ${ }^{10}$ but the ocular conditions underlying this association and the potential implications are unclear. Amongst different eye diseases, obesity has been associated with cataract $1,21,53,63,86,94,107,108,121,129,168,211,222$ age-related maculopathy, $2,28,167,173$ diabetic retinopathy, $8,24,83,114,171,207$ and glaucoma. $60,127,225$

However, these associations have not been consistently documented. The purpose of this article is to review the potential ocular effects of obesity.

\section{Obesity and Eye OBESITY AND CATARACT}

Obesity has been proposed to be a risk factor for cataract development, though the exact underlying mechanisms are unclear. The relationship between obesity and cataract has been investigated in many epidemiological studies, 10, 21, 22, 53, 63, 74, 86, 94, 107, 108, 121, $126,129,144,168,197,211,222$ but the findings are not universally consistent (Table 1). The strongest evidence are based on prospective data from several large population-based studies demonstrating positive association between obesity and cataract. $.3,73,86,107,168,211$ In $1995^{63}$ and 2000, 168 the Physicians' Health Study, a randomized trial of 22071 healthy male American physicians aged 40-84 years, reported both overall obesity, measured as BMI, and abdominal adiposity, measured as waist-to-hip ratio (WHR), as independent risk factors for cataract. It was found that at any given level of BMI, a 2-unit higher level predicted a $12 \%$ increase risk of cataract. 63 The Nurses' Health Study, a large prospective study of female nurses in 1993, also found a higher rate of cataract surgery for women with BMI levels of 23 or greater compared to women with lower levels. ${ }^{73}$ Subsequently, the Nurses' Health and the Health Professionals Follow-up Study generated further results, reporting that obesity increases risk of cataract overall, but in particular, of posterior subcapsular (PSC) type, even after adjusting for variables such as smoking, age and diabetes. ${ }^{211}$ Prospective data from the Framingham Eye Study also demonstrates an independent association between greater BMI and higher incident of cortical and PSC opacities. ${ }^{86}$ Further support on the positive association between obesity and cataract is derived from cross-sectional data from other population-based, 
1, 21, 94, 121, 129, 222 and hospital-based studies, 126, 197 although not all studies have been consistent. For example, using standardized photography to grade lens opacities, the Beaver Dam Eye Study, a cohort study of almost 5000 white Americans, found no significant associations of obesity with either incident cataract or cataract extraction at the baseline or the 5 -year follow-up examination. ${ }^{108,110}$ Nonetheless, 10 -year prospective data from this study showed an association between higher BMI and increased risk of PSC cataract in persons without diabetes. 107

There have also been inconsistencies regarding the types of cataract associated with obesity in these studies. Cortical and PSC cataracts have been most consistently associated with obesity. 1, 21, 121, 129, 222 Among these studies, the Barbados Eye Study in African Americans found higher WHR to be associated with cortical opacities. ${ }^{129}$ The Blue Mountain Eye Study in white Australians suggested that obese persons (BMI of $30 \mathrm{~kg} / \mathrm{m}^{1}$ or greater) have about halfand twofold increase risk of having cortical and PSC cataracts respectively. ${ }^{22}$ In the AgeRelated Eye Disease Study (AREDS), both higher BMI and weight gain were found to have significant association with moderate cortical cataract, independent of age and gender. ${ }^{1} \mathrm{But}$ this association was not statistical significant in the fully adjusted model.

Several plausible pathophysiological mechanisms have been proposed to explain the association of obesity and cataract. One theory suggests that leptin, a 16-kDa pleiotropic cytokine expressed and secreted mainly by adipocytes, ${ }^{227}$ is involved in the molecular mechanisms underlying cataract formation. ${ }^{64}$ Studies have discovered that individuals with obesity likely exhibit hyperleptinemia and leptin resistance. ${ }^{59,78,79,149}$ Leptin has also been found to increase accumulation of reactive oxygen species in various cellular models. 14, 219 This link between obesity, hyperleptinemia and increased oxidative stress has been further reinforced by a subsequent study revealing a strong positive association between BMI and systemic oxidative stress as determined from creatinine-indexed urinary concentrations of 8-epi-prostaglandin F2 $\alpha .{ }^{103}$ In addition, recent studies have proposed that oxidative stress may play an important pathogenic role in cataract formation. ${ }^{11}$, 58, 90, 161, 187, 188, 189, 190 In view of these links, hyperleptinemia associated with obesity may promote cataract formation. Nevertheless, the exact mechanism by which leptin contributes in the process of cataractogenesis is still unclear. Apart from leptin, elevated levels of C-reactive protein and plasma fibrinogen were also found in obese individuals, $32,52,71,209$ and recently these markers of inflammation, such as fibrinogen, have been suggested to have association with cataract. 65,169 Furthermore, obesity has also been linked to cataract by its associated complications such as diabetes, $1,52,115,127,130,183$ glucose intolerance, insulin resistance, 69 hyperlipidemia and hypertension. They are all known risk factors for cataract, $74,96,101$, $129,197,211,222$ but the primary role of these factors in catarctogenesis is less clear.

While the majority of data suggest that higher BMI is associated with cataract, there has been a body of literature that lower BMI may also be a risk factor for some forms of cataract, ${ }^{21}$, 22, 126 particularly in non-white populations. ${ }^{53,121,144}$ Among Chinese people in the Shihpai Eye Study in Taiwan, for example, whereas higher BMI was associated with cortical opacity, lower BMI was associated with nuclear opacity. ${ }^{121}$ In the Tanjong Pagar Survey in Chinese Singaporeans, lower BMI was an independent risk factor for cataract, particularly for cortical cataract. ${ }^{53}$ There has been no clear explanation for this pattern of associations. It has been suggested that lower BMI reflects poor nutritional status and malnutrition in developing countries is a potential risk factor for cataract. ${ }^{198}$ However, not all Asian data suggest this pattern, and a study in India found no association between lower BMI and age-related cataract. 205

Finally, there is no evidence that weight loss prevents cataract formation. Although several studies have proposed that weight loss and reduction of abdominal obesity would likely lessen 
incidence and costs of cataract, 96,168 the efficacy of obesity treatment in reducing risk of cataract has never been evaluated in clinical trials.

In summary, based on the current data, obesity is likely associated with cataract. However, there is still controversy regarding which type of cataract is related to obesity. There are varying patterns and strengths of association for different cataract types, suggesting possible existence of distinct etiological pathways for the different types of cataracts. 212 The reason for the disparity of findings may also partly be due to racial/ethnic differences in population groups and use of different grading systems for cataract and lens opacities.

\section{OBESITY AND GLAUCOMA}

In contrast to cataract, there are less data addressing the relationship between obesity and glaucoma, although there have been several studies that have provided evidence in support of a positive association between obesity and intraocular pressure (IOP) (Table 2), the strongest risk factor for glaucomatous optic neuropathy (GON). $9,66,99,127,140,185$

Most epidemiological studies have been focusing on the association between obesity and IOP or ocular hypertension. Population-based data from several studies have demonstrated independent cross-sectional association between obesity and ocular hypertension. 17, 95, 109, 125, 148, 175, 177, 218, 221 The Beaver Dam Eye Study reported a significantly positive association of IOP with several factors including BMI. ${ }^{109}$ This was consistent with findings from a subsequent hospital-based study, indicating that ocular hypertension risk was significantly greater in persons with BMI of 30 or greater, independent of age and sex. 95 Studies of the Asian populations generated similar results. $125,146,175,221$ In a large population-based study of 25,216 Japanese aged 14-94 years, a positive association between obesity and ocular hypertension was evident in both longitudinal and cross-sectional analysis, even after controlling for age, gender and blood pressure. ${ }^{146}$ This was further reinforced by another large population-based study of Koreans. ${ }^{125}$ Some studies further suggest that the association between obesity and ocular hypertension may reflect underlying association between insulin resistance and ocular hypertension, as the association between obesity measures and IOP was not significant after adjustments for glucose and other confounders. 152

On the contrary, only few studies have directly examined the association between BMI and GON. The limited data generated from these studies demonstrate noticeable inconsistency. Firstly, cross-sectional data from the Barbados Eye Study suggested some protective effect of higher BMI with risk of open-angle glaucoma. 127 The analysis, however, only controlled for age and not other factors, and the possibility of incomplete adjustment for confounders cannot be excluded. Secondly, a hospital-based study, relying on review of medical records, reported that patients with higher BMI were more likely to have a clinical diagnosis of glaucoma on admission. ${ }^{225}$ Lastly, in a case-control study, comparing persons with and without glaucoma, no statistically significant difference in BMI was identified. 60

A clear pathophysiological explanation for the association of obesity with IOP and glaucoma is currently lacking. Both the 'mechanical' and 'vascular' etiology theories of glaucoma may be related to obesity. With regards to the mechanical theory, ${ }^{72}$ obesity has been postulated to exert an effect on IOP by causing excessive intraorbital adipose tissue, increased blood viscosity, increased episcleral venous pressure, and impairment of aqueous outflow facility. 17, 166, 176, 177 Furthermore, ocular hypertension has been associated with obesity-related systemic diseases such as hypertension, 13, 37, 106, 128, 138, 200, 218 diabetes, 152 dyslipidemia, 95 and insulin resistance. ${ }^{147,152,218}$ Increased blood pressure may lead to an increased filtration fraction of the aqueous humor through elevated ciliary artery pressure, 17 , 82,177 while hyperglycemia may induce osmotic fluid shift into the intraocular space. 141 
Both mechanisms can ultimately result in elevated IOP. On the other hand, the vascular theory suggests that eyes with inherently poor vascular supply to the optic nerve head are more predisposed to damage by elevated or normal IOP. 38,134 Impaired vascular supply may be related to abnormal ocular blood flow and perfusion instability secondary to alternations in autonomic and endothelial function. $16,49,68,70,75,100$ Obesity has been shown to cause both vascular endothelial dysfunction 62,223 and autonomic dysfunction, particularly in people with diabetes. ${ }^{132,135}$ In addition, cellular factors, including neurotropin deprivation, release of excitatory amino acids, and oxidative stress, have also been suggested to contribute to GON on the molecular level. ${ }^{18,46,61,93,145,153,154,159,165,229}$ Among these, oxidative stress has recently gained intense interest. ${ }^{18,46,61,93,145,153,165,229}$ Increased oxidative DNA damage was found in the trabecular meshwork of glaucoma patients, 93 and oxidative stress has been postulated to cause proteasome failure and induce human trabecular meshwork degeneration, leading to impairment of the ability of the tissue to modulate outflow resistance. ${ }^{18}$ As discussed previously, hyperleptinemia, which is closely related to obesity, is associated with increased oxidative stress. ${ }^{14,31,59,78,79,103,149,219}$ Therefore, theoretically, obesity-associated hyperleptinemia may cause an increase in systemic oxidative stress, priming the glaucoma pathogenetic cascade. ${ }^{165,229}$

The impact of weight loss on IOP and the development or progression of glaucoma has never been investigated. Although people with ocular hypertension may not develop glaucoma, 105 recent meta-analysis of several methodologically adequate trials revealed that primary prevention of glaucomatous visual field defects in patients with ocular hypertension by using topical pressure lowering agents seems to be effective. ${ }^{38,134}$ This raises the possibility that weight reduction, with adjuvant medical therapy, in obese patients with raised IOP may help preventing the development and progression of GON.

In summary, there is considerable evidence from clinical studies to support an association between obesity with higher IOP. However, current evidence of a direct association between obesity and GON is weak. The possible pathogenic role of obesity in GON remains uncertain as most of the etiologic links are still at the hypothetical level. Further studies are warranted to clarify whether obesity is truly a risk factor for glaucoma.

\section{OBESITY AND AGE-RELATED MACULOPATHY}

Age-related maculopathy (ARM) remains a major blinding condition in elderly people, despite the introduction of several new treatment modalities, including photodynamic therapy, 27, 76, 136, 217 novel pharmacological approaches to inhibit angiogenesis $34,47,67,170$ and the use of antioxidant supplement. 27,88

The relationship between obesity and ARM has been investigated in several studies (Table 3). Hirvela and colleagues 87 were the first to observe a positive association between obesity and ARM. This association was subsequently supported by epidemiological data from several large population-based studies. ${ }^{36,108,167,184}$ Prospective data from the Physicians' Health Study demonstrated that the 15-year incidence for visually significant dry ARM was highest in obese men and lowest in men with normal BMI, even after controlling for age and cigarette smoking. 167 However, the study could not find any significant association between obesity and neovascular ARM, which was possibly due to small number of cases in the studied population. The AREDS has reported cross-sectional association between higher BMI and more advanced ARM, as documented from fundus photographs. ${ }^{2}$ A more recent report in 2005 among patients with baseline early or intermediate ARM showed that greater BMI was significantly associated with incident geographic atrophy and progression to advanced ARM with visual impairment, even after controlling for multiple factors including age, gender and treatment. 28 These findings are supported by cross-sectional data from the Blue Mountains Eye Study, although the Beaver Dam Eye Study only found this association in women, but not in men. 108 The 
Pathologies Oculaires Liées à l'Age (POLA) Study of large number of Europeans found that individuals with obesity have a two-fold increase in risk for developing late but not early ARM, 36 although adjustment for other variables such as smoking were not performed.

The pathophysiological mechanisms accountable for the probable association between obesity and ARM are unclear. ARM is a multifactorial disease with some common downstream pathophysiologic pathways leading to the spectrum of retinal signs seen clinically. 89,120 , 164,226 Obesity has been hypothesized to be linked to some of these pathways. As discussed previously, obesity may increase systemic oxidative stress secondary to hyperleptinemia. ${ }^{14}$, $31,59,78,79,103,149,219$ There is compelling evidence that oxidative stress plays an important role in the pathogenesis of ARM. ${ }^{120,164,186,226}$ Oxidative damage to lipids in Bruch membrane appears to be important in the etiology of choroidal neovascular ARM. 186 In response to excessive oxidative stress, the RPE cells may detach and migrate into the subretinal space or outer retina and secrete excessive vascular endothelial growth factor (VEGF), eliciting invasion of neovascularization in Bruch membrane. ${ }^{186}$ Given this, obesity may have a role in the development of ARM because of its associated hyperliptinemia-induced oxidative stress. Nevertheless, a study examining the association of plasma leptin with ARM found paradoxical results; plasma leptin was negatively correlated with severity of ARM, after controlling for age, sex and BMI. It was suggested by the authors that reduced leptin levels could result in loss of its lipidostatic function in cellular level, leading to an increased intracellular fatty acid accumulation within the lesions found in ARM patients. ${ }^{44}$ Studies has also shown that plasma fibrinogen and other markers of inflammation (e.g., C-reactive protein) may be associated with late ARM, ${ }^{184}$ suggesting that inflammation may play a role in ARM development. Plasma fibrinogen and C-reactive protein, for example, are elevated in both adults and children with obesity, 6,206 and may therefore be a potential link between obesity and ARM. Finally, other proposed risk factors for ARM, including hypertension 2, 36, 91, 92, 116 and hyperlipidemia, ${ }^{112,210}$ are also well-known conditions associated with obesity, raising the possibility that obesity may cause ARM by secondary effects from its associated complications.

Apart from an association between BMI and ARM, central obesity, as defined by the waist circumference or WHR, has also been found to increase risk of progression to advanced ARM in one study, ${ }^{173}$ although not in another. ${ }^{143}$ As with the association of BMI and cataract, there are also some conflicting data, based on a smaller number of studies, indicating that lean body mass may increase risk of ARM. ${ }^{115}, 167,183$

In summary, there is considerable evidence that supports an association between obesity and ARM. The nature of this association with the different types of ARM and the role of weight loss in preventing the development or slowing the progression of ARM, however, remains to be determined.

\section{OBESITY AND DIABETIC RETINOPATHY}

The association between obesity and diabetic retinopathy has been investigated in several studies. Most, $8,35,113,203,207,213,228$ but not all, 23, 41, 114, 124, 150 studies have documented a relationship between higher BMI and increased risk of retinopathy (Table 4). Few of these studies, however, have prospective data. ${ }^{8,24,83,114}$ A study in Sweden examined 582 young (aged 15-34) individuals with diabetes (79\% type 1 diabetes) with 10 years follow-up, and found that individuals with higher BMI developed retinopathy at earlier stage. ${ }^{83}$ The EURODIAB Prospective Complications Study of 764 individuals with type 1 diabetes after more than 7 years of follow-up reported WHR as an independent risk factor for diabetic retinopathy. ${ }^{24}$ However, conflicting data were generated in the Wisconsin Epidemiologic Study of Diabetic Retinopathy (WESDR). 113, 114 Although obesity (BMI $>31.0 \mathrm{~kg} / \mathrm{m}^{1}$ for men and $32.1 \mathrm{~kg} / \mathrm{m}^{1}$ for women) was found to associate with progression 
and severity of retinopathy, these associations were not statistically significant and were limited to only individuals with older-onset insulin-independent diabetes. ${ }^{113}$ On the other hand, for those who were underweight (BMI $<20 \mathrm{~kg} / \mathrm{m}^{1}$ ), a 3-fold increase in risk of developing retinopathy was demonstrated. ${ }^{114}$ Underweight has been suggested to be a marker of the more "severe" phase of diabetes, or an indicator of late-onset type 1 diabetes. 113

There are new data that show obesity is associated with retinopathy signs in the general population and non-diabetic persons. In the Hoorn Study in the Netherlands, WHR was also independently associated with a number of incident retinopathy signs, including retinal hemorrhages, microaneurysms, hard exudates and cotton-wool spots in the non-diabetic general population, although the association with BMI failed to achieve statistical significance. 208

The underlying pathophysiological mechanisms of the possible association between obesity and retinopathy are not understood. ${ }^{40}$ Epidemiological data from various studies have identified hyperlipidemia $25,26,29,33,48,111,117,147,150,193$ and hypertension 110 , $119,192,196$ as risk factors for diabetic retinopathy. Both conditions are common risk factors of obesity. In fact, metabolic syndrome, encompassing these conditions, has also been shown to be associated with retinopathy. 213

However, there is also evidence that obesity may have a more direct role in the development of retinopathy. Several pathogenetic theories of diabetic retinopathy exist based on the potential roles of aldose reductase activity, vasoproliferative factors, oxidative stress, platelet function and blood viscosity. Of these, vasoproliferative factors, such as the vascular endothelial growth factor (VEGF), have recently gained intense interest. The concentration of VEGF has been found to be higher in the vitreous of eyes with proliferative diabetic retinopathy. ${ }^{5}$ Serum angiogenic factors, including VEGF, have been observed to be elevated in obese human. ${ }^{142,}$ 179 These findings provide a potential link between obesity and proliferative diabetic retinopathy. Moreover, oxidative stress has also been suggested to contribute in the pathogenesis of diabetic retinopathy, ${ }^{19,} 156$ possibly by inducing over-expression of VEGF and cause features of diabetic retinopathy including retinal neovascularization and macular edema. ${ }^{19,178}$ Finally, as discussed in previous sections, obesity may increase oxidative stress because of its associated hyperleptinemia. 14, 31, 59, 78, 79, 103, 149, 219 High levels of plasma leptin have been found to relate to both hypertensive $4,172,194,203$ and diabetic retinopathy. 57,203 Detailed pathophysiological pathways leading to hypertensive retinopathy has been described elsewhere, ${ }^{215}$ but leptin has been postulated to worsen hypertension by activation of the sympathetic nervous system, accelerating the development of hypertensive retinopathy. ${ }^{80}$ Positive association between severity of hypertensive retinopathy and plasma leptin, independent of BMI, has been reported. 204 Apart from leptin, other adipocytokines have also been investigated, but the evidence to support their roles in the pathogenesis of retinopathy is currently weak. $42,45,56,137,220$

The impact of weight loss, particularly in obese individuals, on regression of retinopathy has been inadequately investigated. ${ }^{174}, 195$ Lifestyle changes, such as weight loss, has been advocated as a key factor in helping prevent diabetes and to delay diabetic complications including retinopathy in susceptible patients. ${ }^{174}$ However, patients with type 1 diabetes and anorexia nervosa with weight loss have also been observed to have higher risk of developing early retinopathy. 195 In spite of the insufficient data, it is generally accepted that weight reduction should be advised in obese diabetic individuals to reduce the risk of cardiovascular disease $118,180,181,182,191,201,202,216$ and possibly diabetic retinopathy. 224 


\section{OBESITY AND OTHER EYE DISEASES}

Obesity has been recognized as a significant risk factor for retinal vein occlusion in a very limited number of studies. 7, 214 In the ARIC and Cardiovascular Health Studies (CHS), obese persons were found to have a nearly four-fold increased risk of having retinal vein occlusion, and there was a significant trend of increasing risk across all quartiles of BMI. ${ }^{214}$ Moreover, retinal venous and arterial occlusions are known to be associated with hypertension, diabetes mellitus and hypercoagulability or hyperviscosity syndromes. $122,157,162,214$ In addition to the known associations of obesity with hypertension and diabetes, several reviews have presented some evidence supporting the association of hypercoagulability disorders with obesity and metabolic syndrome. ${ }^{3,151}$ This provides further support for the possible association between obesity and retinal vascular occlusive diseases.

Other ophthalmic conditions may also be associated with obesity. For example, it has been suggested that obesity may be related to oculomotor nerve palsy. ${ }^{199}$ Obesity has also been associated with recurrent lower eyelid entropion. ${ }^{160}$ Obstructive sleep apnea syndrome, a common co-morbid condition related to obesity, has been associated with papilledema 158 and floppy eyelid syndrome. ${ }^{139}$ Moreover, obesity is also a risk factor for benign intracranial hypertension (pseudotumor cerebri). ${ }^{15,102,163}$ It has been postulated that central obesity may increase intracranial pressure by increasing intra-abdominal, and subsequently pleural, pressure, with a resultant increase of cardiac filling pressure, impeding venous return from the brain. ${ }^{15}$ This suggestion, however, is not agreed by all investigators. ${ }^{131}$ And finally, PraderWilli syndrome, an obesity-associated condition, was found to be related with a number of ocular abnormalities including myopia, astigmatism, amblyopia, strabismus and exotropia. 84

\section{Future Research}

This review suggests that further research is required to fully understand the relationship between obesity and eye diseases. Several lines of investigation are suggested. First, given the growing epidemic of childhood obesity, the lack of data on the ocular effects of obesity early in life needs to be addressed. Secondly, as this review shows, prospective studies are lacking for many of the associations identified from the cross-sectional data. For example, the associations between obesity and IOP, while consistent, are largely based on cross-sectional data, and there are no studies that show obesity is associated with an demonstrable increase in IOP over time. Third, because obesity is closely related to dietary habits, there is a need to study the effect of dietary risk factors on the association of obesity and eye diseases. Fourth, because the criteria for obesity and the dietary habits varies widely between racial/ethnic groups, further studies are needed to address the potential ocular effects of obesity in different racial/ethnic populations. The association between obesity and ARM is an example where studies have only been conducted in white populations. Fifth, the pathophysiological mechanisms underlying the reported associations identified in the epidemiological studies are unknown, and remain as speculations. Thus, additional experimental, cellular or molecular studies may broaden our understanding of the impact of obesity on eye health. Six, most studies have only provided information about how obesity, defined as BMI, weight or WHR, relates to the different eye diseases, and the impact of weight change (weight gain or loss) on eye diseases is less clear. Weight change is more clinically relevant and useful in terms of guiding management. Future epidemiological studies should therefore concentrate on the association of weight change and risk of eye diseases. Finally, in contrast to systemic diseases, there are no clinical trials to demonstrate the potential ocular benefits of weight loss. If weight loss is proven to be an effective method, either as a sole or adjuvant treatment, in delaying the onset or slowing the progression of eye diseases in obese individuals, both clinicians and patients will likely gain additional incentive to battle against this major public health problem. 


\section{Conclusion}

Obesity is a major public health problem and its impact on ocular health is increasing recognized. Associations of obesity with cataract, glaucoma, age-related maculopathy and retinopathy have been reported with varying degree of certainty. The inconsistency of results, combined with the deficiency of robust data, suggest that further investigations are required to clarify these associations. The efficacy of obesity treatment in reducing the risk of eye diseases is also unknown, but studies in this area may provide important insight for the potential use of weight loss strategies to reduce the burden of eye diseases in individuals with obesity.

\section{Method of Literature Search}

A systematic MEDLINE search on National Institute of Health's PubMed

(http://www.ncbi.nlm.nih.gov/entrez/query.fcgi?DB=pubmed) with coverage up to 18 August 2005 was conducted initially using the following keywords: "obesity, body mass index, waistto-hip ratio, weight, risk factor" in various combinations with "eye (368 citations), eye disease (725), ocular (225), cataract (66), lens opacity (48), glaucoma (37), intraocular pressure (32), maculopathy (13), diabetic retinopathy (24), hypertensive retinopathy (34), retinal arterial occlusion (8), retinal venous occlusion (10)”. After review of abstracts, relevant articles were retrieved and reviewed. All English articles were read, and for the relevant non-English articles, the English abstracts were reviewed. Bibliographies of these articles provided further references, including books and internet-based data.

\section{Acknowledgments}

This article was partially funded by NIH grant R21-HL077166, the Science, Technology Innovation (STI) Grant and the Sylvia and Charles Viertel Clinical Investigator Award, Australia (TYW). The authors reported no proprietary or commercial interest in any product mentioned or cnocept discussed in this review.

\section{References}

1. Risk factors associated with age-related nuclear and cortical cataract : a case-control study in the AgeRelated Eye Disease Study, AREDS Report No. 5. Ophthalmology 2001;108:1400-8. [PubMed: 11470690]

2. Risk factors associated with age-related macular degeneration. A case-control study in the age-related eye disease study: Age-Related Eye Disease Study Report Number 3. Ophthalmology 2000;107:222432. [PubMed: 11097601]

3. Abramson N, Abramson S. Hypercoagulability: clinical assessment and treatment. South Med J 2001;94:1013-20. [PubMed: 11702813]

4. Agata J, Masuda A, Takada M, et al. High plasma immunoreactive leptin level in essential hypertension. Am J Hypertens 1997;10:1171-4. [PubMed: 9370390]

5. Aiello LP, Avery RL, Arrigg PG, et al. Vascular endothelial growth factor in ocular fluid of patients with diabetic retinopathy and other retinal disorders. N Engl J Med 1994;331:1480-7. [PubMed: 7526212]

6. Alam AA, Mitwalli AH, Al-Wakeel JS, et al. Plasma fibrinogen and its correlates in adult Saudi population. Saudi Med J 2004;25:1593-602. [PubMed: 15573185]

7. Backhouse O, Parapia L, Mahomed I, et al. Familial thrombophilia and retinal vein occlusion. Eye 2000;14 ( Pt 1):13-7. [PubMed: 10755093]

8. Ballard DJ, Melton LJ, Dwyer MS, et al. Risk factors for diabetic retinopathy: a population-based study in Rochester, Minnesota. Diabetes Care 1986;9:334-42. [PubMed: 3743309]

9. Bengtsson B, Heijl A. A long-term prospective study of risk factors for glaucomatous visual field loss in patients with ocular hypertension. J Glaucoma 2005;14:135-8. [PubMed: 15741815] 
10. Bergman B, Nilsson-Ehle H, Sjöstrand J. Ocular changes, risk markers for eye disorders and effects of cataract surgery in elderly people: a study of an urban Swedish population followed from 70 to 97 years of age. Acta Ophthalmol Scand 2004;82:166-74. [PubMed: 15043535]

11. Bhuyan KC, Bhuyan DK, Podos SM. Lipid peroxidation in cataract of the human. Life Sci 1986;38:1463-71. [PubMed: 3702587]

12. Bianchini F, Kaaks R, Vainio H. Weight control and physical activity in cancer prevention. Obes Rev 2002;3:5-8. [PubMed: 12119660]

13. Bonomi L, Marchini G, Marraffa M, et al. Vascular risk factors for primary open angle glaucoma: the Egna-Neumarkt Study. Ophthalmology 2000;107:1287-93. [PubMed: 10889099]

14. Bouloumie A, Marumo T, Lafontan M, et al. Leptin induces oxidative stress in human endothelial cells. FASEB J 1999;13:1231-8. [PubMed: 10385613]

15. Brazis PW, Lee AG. Elevated intracranial pressure and pseudotumor cerebri. Curr Opin Ophthalmol 1998;9:27-32. [PubMed: 10387332]

16. Broadway DC, Drance SM. Glaucoma and vasospasm. Br J Ophthalmol 1998;82:862-70. [PubMed: 9828767]

17. Bulpitt CJ, Hodes C, Everitt MG. Intraocular pressure and systemic blood pressure in the elderly. $\mathrm{Br}$ J Ophthalmol 1975;59:717-20. [PubMed: 1218183]

18. Caballero M, Liton PB, Epstein DL, et al. Proteasome inhibition by chronic oxidative stress in human trabecular meshwork cells. Biochem Biophys Res Commun 2003;308:346-52. [PubMed: 12901875]

19. Caldwell RB, Bartoli M, Behzadian MA, et al. Vascular endothelial growth factor and diabetic retinopathy: role of oxidative stress. Curr Drug Targets 2005;6:511-24. [PubMed: 16026270]

20. Calle EE, Rodriguez C, Walker-Thurmond K, et al. Overweight, obesity, and mortality from cancer in a prospectively studied cohort of U.S. adults. N Engl J Med 2003;348:1625-38. [PubMed: 12711737]

21. Caulfield LE, West SK, Barrón Y, et al. Anthropometric status and cataract: the Salisbury Eye Evaluation project. Am J Clin Nutr 1999;69:237-42. [PubMed: 9989686]

22. Chatterjee A, Milton RC, Thyle S. Prevalence and aetiology of cataract in Punjab. Br J Ophthalmol 1982;66:35-42. [PubMed: 7055541]

23. Chaturvedi N, Fuller JH. Mortality risk by body weight and weight change in people with NIDDM. The WHO Multinational Study of Vascular Disease in Diabetes. Diabetes Care 1995;18:766-74. [PubMed: 7555501]

24. Chaturvedi N, Sjoelie AK, Porta M, et al. Markers of insulin resistance are strong risk factors for retinopathy incidence in type 1 diabetes. Diabetes Care 2001;24:284-9. [PubMed: 11213880]

25. Chew EY. Diabetic retinopathy and lipid abnormalities. Curr Opin Ophthalmol 1997;8:59-62. [PubMed: 10168895]

26. Chew EY, Klein ML, Ferris FL, et al. Association of elevated serum lipid levels with retinal hard exudate in diabetic retinopathy. Early Treatment Diabetic Retinopathy Study (ETDRS) Report 22. Arch Ophthalmol 1996;114:1079-84. [PubMed: 8790092]

27. Chopdar A, Chakravarthy U, Verma D. Age related macular degeneration. BMJ 2003;326:485-8. [PubMed: 12609947]

28. Clemons TE, Milton RC, Klein R, et al. Risk factors for the incidence of Advanced Age-Related Macular Degeneration in the Age-Related Eye Disease Study (AREDS) AREDS report no. 19. Ophthalmology 2005;112:533-9. [PubMed: 15808240]

29. Cohen RA, Hennekens CH, Christen WG, et al. Determinants of retinopathy progression in type 1 diabetes mellitus. Am J Med 1999;107:45-51. [PubMed: 10403352]

30. Cole TJ, Bellizzi MC, Flegal KM, et al. Establishing a standard definition for child overweight and obesity worldwide: international survey. BMJ 2000;320:1240-3. [PubMed: 10797032]

31. Considine RV, Sinha MK, Heiman ML, et al. Serum immunoreactive-leptin concentrations in normalweight and obese humans. N Engl J Med 1996;334:292-5. [PubMed: 8532024]

32. Cushman M, Yanez D, Psaty BM, et al. Association of fibrinogen and coagulation factors VII and VIII with cardiovascular risk factors in the elderly: the Cardiovascular Health Study. Cardiovascular Health Study Investigators. Am J Epidemiol 1996;143:665-76. [PubMed: 8651228] 
33. Cusick M, Chew EY, Chan CC, et al. Histopathology and regression of retinal hard exudates in diabetic retinopathy after reduction of elevated serum lipid levels. Ophthalmology 2003;110:212633. [PubMed: 14597519]

34. D'Amico DJ, Goldberg MF, Hudson H, et al. Anecortave acetate as monotherapy for treatment of subfoveal neovascularization in age-related macular degeneration: twelve-month clinical outcomes. Ophthalmology 2003;110:2372-83. [PubMed: 14644721]discussin 2384-5

35. De Block CE, De Leeuw IH, Van Gaal LF. Impact of overweight on chronic microvascular complications in type 1 diabetic patients. Diabetes Care 2005;28:1649-55. [PubMed: 15983315]

36. Delcourt C, Michel F, Colvez A, et al. Associations of cardiovascular disease and its risk factors with age-related macular degeneration: the POLA study. Ophthalmic Epidemiol 2001;8:237-49. [PubMed: 11471092]

37. Dielemans I, Vingerling JR, Algra D, et al. Primary open-angle glaucoma, intraocular pressure, and systemic blood pressure in the general elderly population. The Rotterdam Study. Ophthalmology 1995;102:54-60. [PubMed: 7831042]

38. Dielemans I, Vingerling JR, Wolfs RC, et al. The prevalence of primary open-angle glaucoma in a population-based study in The Netherlands. The Rotterdam Study. Ophthalmology 1994;101:18515. [PubMed: 7800368]

39. Dietz WH. Overweight in childhood and adolescence. N Engl J Med 2004;350:855-7. [PubMed: 14985480]

40. Dorchy H, Claes C, Verougstraete C. Risk factors of developing proliferative retinopathy in type 1 diabetic patients : role of BMI. Diabetes Care 2002;25:798-9. [PubMed: 11919142]

41. Dowse GK, Humphrey AR, Collins VR, et al. Prevalence and risk factors for diabetic retinopathy in the multiethnic population of Mauritius. Am J Epidemiol 1998;147:448-57. [PubMed: 9525531]

42. Duntas LH, Popovic V, Panotopoulos G. Adiponectin: novelties in metabolism and hormonal regulation. Nutr Neurosci 2004;7:195-200. [PubMed: 15682645]

43. Eckel RH, Krauss RM. American Heart Association call to action: obesity as a major risk factor for coronary heart disease. AHA Nutrition Committee. Circulation 1998;97:2099-100. [PubMed: 9626167]

44. Evereklioglu C, Doganay S, Er H, et al. Serum leptin concentrations are decreased and correlated with disease severity in age-related macular degeneration: a preliminary study. Eye 2003;17:350-5. [PubMed: 12724698]

45. Fasshauer M, Paschke R, Stumvoll M. Adiponectin, obesity, and cardiovascular disease. Biochimie 2004;86:779-84. [PubMed: 15589686]

46. Ferreira SM, Lerner SF, Brunzini R, et al. Oxidative stress markers in aqueous humor of glaucoma patients. Am J Ophthalmol 2004;137:62-9. [PubMed: 14700645]

47. Ferris FL. A new treatment for ocular neovascularization. N Engl J Med 2004;351:2863-5. [PubMed: 15625339]

48. Ferris FL, Chew EY, Hoogwerf BJ. Serum lipids and diabetic retinopathy. Early Treatment Diabetic Retinopathy Study Research Group. Diabetes Care 1996;19:1291-3. [PubMed: 8908399]

49. Flammer F, Orgul S, Costa VP, et al. The impact of ocular blood flow in glaucoma. Prog Retinal Eye Res 2002;21:359-93.

50. Flegal KM, Carroll MD, Kuczmarski RJ, et al. Overweight and obesity in the United States: prevalence and trends, 1960-1994. Int J Obes Relat Metab Disord 1998;22:39-47. [PubMed: 9481598]

51. Flegal KM, Carroll MD, Ogden CL, et al. Prevalence and trends in obesity among US adults, 19992000. JAMA 2002;288:1723-7. [PubMed: 12365955]

52. Ford ES. Body mass index, diabetes, and C-reactive protein among U.S. adults. Diabetes Care 1999;22:1971-7. [PubMed: 10587828]

53. Foster PJ, Wong TY, Machin D, et al. Risk factors for nuclear, cortical and posterior subcapsular cataracts in the Chinese population of Singapore: the Tanjong Pagar Survey. Br J Ophthalmol 2003;87:1112-20. [PubMed: 12928278]

54. Friedman N, Fanning EL. Overweight and obesity: an overview of prevalence, clinical impact, and economic impact. Dis Manag 2004;7 Suppl 1:S1-6. [PubMed: 15669572] 
55. Friedrich MJ. Epidemic of obesity expands its spread to developing countries. JAMA 2002;287:13826. [PubMed: 11903011]

56. Frystyk J, Tarnow L, Hansen TK, et al. Increased serum adiponectin levels in type 1 diabetic patients with microvascular complications. Diabetologia 2005;48:1911-8. [PubMed: 16078018]

57. Gariano RF, Nath AK, D'Amico DJ, et al. Elevation of vitreous leptin in diabetic retinopathy and retinal detachment. Invest Ophthalmol Vis Sci 2000;41:3576-81. [PubMed: 11006255]

58. Garner MH, Spector A. Selective oxidation of cysteine and methionine in normal and senile cataractous lenses. Proc Natl Acad Sci U S A 1980;77:1274-7. [PubMed: 6929483]

59. Garofalo C, Surmacz E. Leptin and cancer. J Cell Physiol 2006;207:12-22. [PubMed: 16110483]

60. Gasser P, Stümpfig D, Schötzau A, et al. Body mass index in glaucoma. J Glaucoma 1999;8:8-11. [PubMed: 10084268]

61. Gherghel D, Griffiths HR, Hilton EJ, et al. Systemic reduction in glutathione levels occurs in patients with primary open-angle glaucoma. Invest Ophthalmol Vis Sci 2005;46:877-83. [PubMed: 15728543]

62. Głowińska B, Urban M, Hryniewicz A, et al. Endothelin-1 plasma concentration in children and adolescents with atherogenic risk factors. Kardiol Pol 2004;61:329-38. [PubMed: 15841114]

63. Glynn RJ, Christen WG, Manson JE, et al. Body mass index. An independent predictor of cataract. Arch Ophthalmol 1995;113:1131-7. [PubMed: 7661746]

64. Gómez-Ambrosi J, Salvador J, Frühbeck G. Is hyperleptinemia involved in the development of agerelated lens opacities? Am J Clin Nutr 2004;79:888-9. [PubMed: 15113732] author reply 889

65. Goodrich ME, Cumming RG, Mitchell P, et al. Plasma fibrinogen and other cardiovascular disease risk factors and cataract. Ophthalmic Epidemiol 1999;6:279-90. [PubMed: 10544342]

66. Gordon MO, Beiser JA, Brandt JD, et al. The Ocular Hypertension Treatment Study: baseline factors that predict the onset of primary open-angle glaucoma. Arch Ophthalmol 2002;120:714-20. [PubMed: 12049575]discussion 829-30

67. Gragoudas ES, Adamis AP, Cunningham ET, et al. Pegaptanib for neovascular age-related macular degeneration. N Engl J Med 2004;351:2805-16. [PubMed: 15625332]

68. Grieshaber MC, Flammer J. Blood flow in glaucoma. Curr Opin Ophthalmol 2005;16:79-83. [PubMed: 15744136]

69. Grundy SM. Metabolic complications of obesity. Endocrine 2000;13:155-65. [PubMed: 11186217]

70. Grunwald JE, Piltz J, Hariprasad SM, et al. Optic nerve and choroidal circulation in glaucoma. Invest Ophthalmol Vis Sci 1998;39:2329-36. [PubMed: 9804141]

71. Hak AE, Stehouwer CD, Bots ML, et al. Associations of C-reactive protein with measures of obesity, insulin resistance, and subclinical atherosclerosis in healthy, middle-aged women. Arterioscler Thromb Vasc Biol 1999;19:1986-91. [PubMed: 10446082]

72. Halpern DL, Grosskreutz CL. Glaucomatous optic neuropathy: mechanisms of disease. Ophthalmol Clin North Am 2002;15:61-8. [PubMed: 12064082]

73. Hankinson SE, Seddon JM, Colditz GA, et al. A prospective study of aspirin use and cataract extraction in women. Arch Ophthalmol 1993;111:503-8. [PubMed: 8470984]

74. Harding JJ. Recent studies of risk factors and protective factors for cataract. Curr Opin Ophthalmol 1997;8:46-9. [PubMed: 10168273]

75. Harris A, Zarfati D, Zalish M, et al. Reduced cerebrovascular blood flow velocities and vasoreactivity in open-angle glaucoma. Am J Ophthalmol 2003;135:144-7. [PubMed: 12566016]

76. Hart PM, Chakravarthy U, Mackenzie G, et al. Visual outcomes in the subfoveal radiotherapy study: a randomized controlled trial of teletherapy for age-related macular degeneration. Arch Ophthalmol 2002;120:1029-38. [PubMed: 12149056]

77. Haslam DW, James WP. Obesity. Lancet 2005;366:1197-209. [PubMed: 16198769]

78. Hassink SG, Sheslow DV, de Lancey E, et al. Serum leptin in children with obesity: relationship to gender and development. Pediatrics 1996;98:201-3. [PubMed: 8692618]

79. Haynes WG. Role of leptin in obesity-related hypertension. Exp Physiol 2005;90:683-8. [PubMed: 16105937]

80. Haynes WG, Sivitz WI, Morgan DA, et al. Sympathetic and cardiorenal actions of leptin. Hypertension 1997;30:619-23. [PubMed: 9322991] 
81. Hedley AA, Ogden CL, Johnson CL, et al. Prevalence of overweight and obesity among US children, adolescents, and adults, 1999-2002. JAMA 2004;291:2847-50. [PubMed: 15199035]

82. Hennis A, Wu SY, Nemesure B, et al. Hypertension, diabetes, and longitudinal changes in intraocular pressure. Ophthalmology 2003;110:908-14. [PubMed: 12750088]

83. Henricsson M, Nyström L, Blohmé G, et al. The incidence of retinopathy 10 years after diagnosis in young adult people with diabetes: results from the nationwide population-based Diabetes Incidence Study in Sweden (DISS). Diabetes Care 2003;26:349-54. [PubMed: 12547861]

84. Hered RW, Rogers S, Zang YF, et al. Ophthalmologic features of Prader-Willi syndrome. J Pediatr Ophthalmol Strabismus 1988;25:145-50. [PubMed: 3397859]

85. Hill JO, Catenacci V, Wyatt HR. Obesity: overview of an epidemic. Psychiatr Clin North Am 2005;28:1-23. vii. [PubMed: 15733608]

86. Hiller R, Podgor MJ, Sperduto RD, et al. A longitudinal study of body mass index and lens opacities. The Framingham Studies. Ophthalmology 1998;105:1244-50. [PubMed: 9663229]

87. Hirvelä H, Luukinen H, Läärä E, et al. Risk factors of age-related maculopathy in a population 70 years of age or older. Ophthalmology 1996;103:871-7. [PubMed: 8643241]

88. Hogg R, Chakravarthy U. AMD and micronutrient antioxidants. Curr Eye Res 2004;29:387-401. [PubMed: 15764083]

89. Holz FG, Pauleikhoff D, Klein R, et al. Pathogenesis of lesions in late age-related macular disease. Am J Ophthalmol 2004;137:504-10. [PubMed: 15013875]

90. Horwitz, J. Anatomy and embryology. In: Podos, SM.; Yanoff, M., editors. Textbook of Ophthalmology 3, Lens and Cataract. Gower Medical Publishing; New York: 1992.

91. Hyman L, Neborsky R. Risk factors for age-related macular degeneration: an update. Curr Opin Ophthalmol 2002;13:171-5. [PubMed: 12011686]

92. Hyman L, Schachat AP, He Q, et al. Hypertension, cardiovascular disease, and age-related macular degeneration. Age-Related Macular Degeneration Risk Factors Study Group. Arch Ophthalmol 2000;118:351-8. [PubMed: 10721957]

93. Izzotti A, Saccà SC, Cartiglia $\mathrm{C}$, et al. Oxidative deoxyribonucleic acid damage in the eyes of glaucoma patients. Am J Med 2003;114:638-46. [PubMed: 12798451]

94. Jacques PF, Moeller SM, Hankinson SE, et al. Weight status, abdominal adiposity, diabetes, and early age-related lens opacities. Am J Clin Nutr 2003;78:400-5. [PubMed: 12936921]

95. Jaén Díaz J, Sanz Alcolea I, López De Castro F, et al. [Glaucoma and ocular hypertension in primary care]. Aten Primaria 2001;28:23-30. [PubMed: 11412574]

96. Jahn CE, Janke M, Winowski H, et al. Identification of metabolic risk factors for posterior subcapsular cataract. Ophthalmic Res 1986;18:112-6. [PubMed: 3737111]

97. James PT. Obesity: the worldwide epidemic. Clin Dermatol 2004;22:276-80. [PubMed: 15475226]

98. James PT, Leach R, Kalamara E, et al. The worldwide obesity epidemic. Obes Res 2001;9 Suppl 4:228S-233S. [PubMed: 11707546]

99. Jonas JB, Grundler AE, Gonzales-Cortes J, et al. Pressure-dependent neuroretinal rim loss in normalpressure glaucoma. Am J Ophthalmol 1988;125:137-44. [PubMed: 9467438]

100. Kaiser HJ, Flammer J, Wenk M, et al. Endothelin-1 plasma levels in normal-tension glaucoma: abnormal response to postural changes. Graefes Arch Clin Exp Ophthalmol 1995;233:484-8. [PubMed: 8537023]

101. Karasik A, Modan M, Halkin H, et al. Senile cataract and glucose intolerance: the Israel Study of glucose Intolerance Obesity and Hypertension (The Israel GOH Study). Diabetes Care 1984;7:526. [PubMed: 6705665]

102. Kaur H, Hyder ML, Poston WS. Childhood overweight: an expanding problem. Treat Endocrinol 2003;2:375-88. [PubMed: 15981942]

103. Keaney JF, Larson MG, Vasan RS, et al. Obesity and systemic oxidative stress: clinical correlates of oxidative stress in the Framingham Study. Arterioscler Thromb Vasc Biol 2003;23:434-9. [PubMed: 12615693]

104. Kennedy RL, Chokkalingham K, Srinivasan R. Obesity in the elderly: who should we be treating, and why, and how? Curr Opin Clin Nutr Metab Care 2004;7:3-9. [PubMed: 15090896] 
105. Kitazawa Y, Horie T, Aoki S, et al. Untreated ocular hypertension. A long-term prospective study. Arch Ophthalmol 1977;95:1180-4. [PubMed: 880076]

106. Klein BE, Klein R. Intraocular pressure and cardiovascular risk variables. Arch Ophthalmol 1981;99:837-9. [PubMed: 7236086]

107. Klein BE, Klein R, Lee KE. Diabetes, cardiovascular disease, selected cardiovascular disease risk factors, and the 5-year incidence of age-related cataract and progression of lens opacities: the Beaver Dam Eye Study. Am J Ophthalmol 1998;126:782-90. [PubMed: 9860001]

108. Klein BE, Klein R, Lee KE, et al. Measures of obesity and age-related eye diseases. Ophthalmic Epidemiol 2001;8:251-62. [PubMed: 11471093]

109. Klein BE, Klein R, Linton KL. Intraocular pressure in an American community. The Beaver Dam Eye Study. Invest Ophthalmol Vis Sci 1992;33:2224-8. [PubMed: 1607232]

110. Klein BE, Klein R, Moss SE. Incident cataract surgery: the Beaver Dam eye study. Ophthalmology 1997;104:573-80. [PubMed: 9111248]

111. Klein BE, Moss SE, Klein R, et al. The Wisconsin Epidemiologic Study of Diabetic Retinopathy. XIII. Relationship of serum cholesterol to retinopathy and hard exudate. Ophthalmology 1991;98:1261-5. [PubMed: 1923364]

112. Klein R, Klein BE, Franke T. The relationship of cardiovascular disease and its risk factors to agerelated maculopathy. The Beaver Dam Eye Study. Ophthalmology 1993;100:406-14. [PubMed: 8460013]

113. Klein R, Klein BE, Moss SE. Is obesity related to microvascular and macrovascular complications in diabetes? The Wisconsin Epidemiologic Study of Diabetic Retinopathy. Arch Intern Med 1997;157:650-6. [PubMed: 9080919]

114. Klein R, Klein BE, Moss SE, et al. The Wisconsin epidemiologic study of diabetic retinopathy. III. Prevalence and risk of diabetic retinopathy when age at diagnosis is 30 or more years. Arch Ophthalmol 1984;102:527-32. [PubMed: 6367725]

115. Klein R, Klein BE, Tomany SC, et al. The association of cardiovascular disease with the long-term incidence of age-related maculopathy: the Beaver Dam eye study. Ophthalmology 2003;110:63643. [PubMed: 12689879]

116. Klein R, Peto T, Bird A, et al. The epidemiology of age-related macular degeneration. Am J Ophthalmol 2004;137:486-95. [PubMed: 15013873]

117. Klein R, Sharrett AR, Klein BE, et al. The association of atherosclerosis, vascular risk factors, and retinopathy in adults with diabetes : the atherosclerosis risk in communities study. Ophthalmology 2002;109:1225-34. [PubMed: 12093643]

118. Knowler WC, Barrett-Connor E, Fowler SE, et al. Reduction in the incidence of type 2 diabetes with lifestyle intervention or metformin. N Engl J Med 2002;346:393-403. [PubMed: 11832527]

119. Kohner EM, Aldington SJ, Stratton IM, et al. United Kingdom Prospective Diabetes Study, 30: diabetic retinopathy at diagnosis of non-insulin-dependent diabetes mellitus and associated risk factors. Arch Ophthalmol 1998;116:297-303. [PubMed: 9514482]

120. Kopitz J, Holz FG, Kaemmerer E, et al. Lipids and lipid peroxidation products in the pathogenesis of age-related macular degeneration. Biochimie 2004;86:825-31. [PubMed: 15589692]

121. Kuang TM, Tsai SY, Hsu WM, et al. Body mass index and age-related cataract: the Shihpai Eye Study. Arch Ophthalmol 2005;123:1109-14. [PubMed: 16087846]

122. Lahey JM, Kearney JJ, Tunc M. Hypercoagulable states and central retinal vein occlusion. Curr Opin Pulm Med 2003;9:385-92. [PubMed: 12904708]

123. Lawrence VJ, Kopelman PG. Medical consequences of obesity. Clin Dermatol 2004;22:296-302. [PubMed: 15475229]

124. Lee ET, Lee VS, Lu M, et al. Development of proliferative retinopathy in NIDDM. A follow-up study of American Indians in Oklahoma. Diabetes 1992;41:359-67. [PubMed: 1551496]

125. Lee JS, Lee SH, Oum BS, et al. Relationship between intraocular pressure and systemic health parameters in a Korean population. Clin Experiment Ophthalmol 2002;30:237-41. [PubMed: 12121360]

126. Leske MC, Chylack LT, Wu SY. The Lens Opacities Case-Control Study. Risk factors for cataract. Arch Ophthalmol 1991;109:244-51. [PubMed: 1993036] 
127. Leske MC, Connell AM, Wu SY, et al. Risk factors for open-angle glaucoma. The Barbados Eye Study. Arch Ophthalmol 1995;113:918-24. [PubMed: 7605285]

128. Leske MC, Podgor MJ. Intraocular pressure, cardiovascular risk variables, and visual field defects. Am J Epidemiol 1983;118:280-7. [PubMed: 6881131]

129. Leske MC, Wu SY, Hennis A, et al. Diabetes, hypertension, and central obesity as cataract risk factors in a black population. The Barbados Eye Study. Ophthalmology 1999;106:35-41. [PubMed: 9917778]

130. Leske MC, Wu SY, Hyman L, et al. Biochemical factors in the lens opacities. Case-control study. The Lens Opacities Case-Control Study Group. Arch Ophthalmol 1995;113:1113-9. [PubMed: 7661743]

131. Lessell S. Pediatric pseudotumor cerebri (idiopathic intracranial hypertension). Surv Ophthalmol 1992;37:155-66. [PubMed: 1475750]

132. Lim HS, MacFadyen RJ, Lip GY. Diabetes mellitus, the renin-angiotensin-aldosterone system, and the heart. Arch Intern Med 2004;164:1737-48. [PubMed: 15364666]

133. Lobstein T, Baur L, Uauy R, et al. Obesity in children and young people: a crisis in public health. Obes Rev 2004;5 Suppl 1:4-104. [PubMed: 15096099]

134. Maier PC, Funk J, Schwarzer G, et al. Treatment of ocular hypertension and open angle glaucoma: meta-analysis of randomised controlled trials. BMJ 2005;331:134. [PubMed: 15994659]

135. Mapstone R, Clark CV. Prevalence of diabetes in glaucoma. Br Med J (Clin Res Ed) 1985;291:935.

136. Marcus DM, Sheils W, Johnson MH, et al. External beam irradiation of subfoveal choroidal neovascularization complicating age-related macular degeneration: one-year results of a prospective, double-masked, randomized clinical trial. Arch Ophthalmol 2001;119:171-80. [PubMed: 11176977]

137. Matsuda M, Kawasaki F, Yamada K, et al. Impact of adiposity and plasma adipocytokines on diabetic angiopathies in Japanese Type 2 diabetic subjects. Diabet Med 2004;21:881-8. [PubMed: 15270792]

138. McLeod SD, West SK, Quigley HA, et al. A longitudinal study of the relationship between intraocular and blood pressures. Invest Ophthalmol Vis Sci 1990;31:2361-6. [PubMed: 2243000]

139. McNab AA. The eye and sleep. Clin Experiment Ophthalmol 2005;33:117-25. [PubMed: 15807817]

140. Mitchell P, Smith W, Attebo K, et al. Prevalence of open-angle glaucoma in Australia. The Blue Mountains Eye Study. Ophthalmology 1996;103:1661-9. [PubMed: 8874440]

141. Mitchell P, Smith W, Chey T, et al. Open-angle glaucoma and diabetes: the Blue Mountains eye study, Australia. Ophthalmology 1997;104:712-8. [PubMed: 9111268]

142. Miyazawa-Hoshimoto S, Takahashi K, Bujo H, et al. Elevated serum vascular endothelial growth factor is associated with visceral fat accumulation in human obese subjects. Diabetologia 2003;46:1483-8. [PubMed: 14534780]

143. Moeini HA, Masoudpour H, Ghanbari H. A study of the relation between body mass index and the incidence of age related macular degeneration. Br J Ophthalmol 2005;89:964-6. [PubMed: 16024844]

144. Mohan M, Sperduto RD, Angra SK, et al. India-US case-control study of age-related cataracts. IndiaUS Case-Control Study Group. Arch Ophthalmol 1989;107:670-6. [PubMed: 2818712]

145. Moreno MC, Campanelli J, Sande P, et al. Retinal oxidative stress induced by high intraocular pressure. Free Radic Biol Med 2004;37:803-12. [PubMed: 15384194]

146. Mori K, Ando F, Nomura H, et al. Relationship between intraocular pressure and obesity in Japan. Int J Epidemiol 2000;29:661-6. [PubMed: 10922342]

147. Nakamura M, Ishimitsu T, Matsuoka H, et al. [Implications of obesity for target organ injuries and cardiovascular risk factors in hypertensive subjects]. Nippon Jinzo Gakkai Shi 1997;39:746-52. [PubMed: 9396243]

148. Nakamura M, Kanamori A, Negi A. Diabetes mellitus as a risk factor for glaucomatous optic neuropathy. Ophthalmologica 2005;219:1-10. [PubMed: 15627820] 
149. Narin F, Atabek ME, Karakukcu M, et al. The association of plasma homocysteine levels with serum leptin and apolipoprotein B levels in childhood obesity. Ann Saudi Med 2005;25:209-14. [PubMed: 16119521]

150. Nelson RG, Wolfe JA, Horton MB, et al. Proliferative retinopathy in NIDDM. Incidence and risk factors in Pima Indians. Diabetes 1989;38:435-40. [PubMed: 2925007]

151. Nieuwdorp M, Stroes ES, Meijers JC, et al. Hypercoagulability in the metabolic syndrome. Curr Opin Pharmacol 2005;5:155-9. [PubMed: 15780824]

152. Oh SW, Lee S, Park C, et al. Elevated intraocular pressure is associated with insulin resistance and metabolic syndrome. Diabetes Metab Res Rev 2005;21:434-40. [PubMed: 15651065]

153. Ohia SE, Opere CA, Leday AM. Pharmacological consequences of oxidative stress in ocular tissues. Mutat Res 2005;579:22-36. [PubMed: 16055157]

154. Olney JW. Inciting excitotoxic cytocide among central neurons. Adv Exp Med Biol 1986;203:63145. [PubMed: 3024464]

155. Pi-Sunyer FX. Medical hazards of obesity. Ann Intern Med 1993;119:655-60. [PubMed: 8363192]

156. Polak M,Zagórski Z. Lipid peroxidation in diabetic retinopathy. Ann Univ Mariae Curie Sklodowska [Med] 2004;59:434-7.

157. Prisco D, Marcucci R. Retinal vein thrombosis: risk factors, pathogenesis and therapeutic approach. Pathophysiol Haemost Thromb 2002;32:308-11. [PubMed: 13679663]

158. Purvin VA, Kawasaki A, Yee RD. Papilledema and obstructive sleep apnea syndrome. Arch Ophthalmol 2000;118:1626-30. [PubMed: 11115256]

159. Quigley HA, Nickells RW, Kerrigan LA, et al. Retinal ganglion cell death in experimental glaucoma and after axotomy occurs by apoptosis. Invest Ophthalmol Vis Sci 1995;36:774-86. [PubMed: 7706025]

160. Raina J, Foster JA. Obesity as a cause of mechanical entropion. Am J Ophthalmol 1996;122:1235. [PubMed: 8659588]

161. Ramachandran S, Morris SM, Devamanoharan P, et al. Radio-isotopic determination of hydrogen peroxide in aqueous humor and urine. Exp Eye Res 1991;53:503-6. [PubMed: 1936185]

162. Robinson MK, Halpern JI. Retinal vein occlusion. Am Fam Physician 1992;45:2661-6. [PubMed: 1595515]

163. Rodríguez de Rivera FJ, Martínez-Sanchez P, Ojeda-Ruiz de Luna J, et al. Benign intracranial hypertension. History, clinical features and treatment in a series of 41 patients. Rev Neurol 3115;37:801-5.

164. Roth F, Bindewald A, Holz FG. Keypathophysiologic pathways in age-related macular disease. Graefes Arch Clin Exp Ophthalmol 2004;242:710-6. [PubMed: 15309554]

165. Saccà SC, Pascotto A, Camicione $\mathrm{P}$, et al. Oxidative DNA damage in the human trabecular meshwork: clinical correlation in patients with primary open-angle glaucoma. Arch Ophthalmol 2005;123:458-63. [PubMed: 15824217]

166. Savinova OV, Sugiyama F, Martin JE, et al. Intraocular pressure in genetically distinct mice: an update and strain survey. BMC Genet 2001;2:12. [PubMed: 11532192]

167. Schaumberg DA, Christen WG, Hankinson SE, et al. Body mass index and the incidence of visually significant age-related maculopathy in men. Arch Ophthalmol 2001;119:1259-65. [PubMed: 11545630]

168. Schaumberg DA, Glynn RJ, Christen WG, et al. Relations of body fat distribution and height with cataract in men. Am J Clin Nutr 2000;72:1495-502. [PubMed: 11101477]

169. Schaumberg DA, Ridker PM, Glynn RJ, et al. High levels of plasma C-reactive protein and future risk of age-related cataract. Ann Epidemiol 1999;9:166-71. [PubMed: 10192648]

170. Schmidt-Erfurth U, Mi chels S, Michels R, et al. Anecortave acetate for the treatment of subfoveal choroidal neovascularization secondary to age-related macular degeneration. Eur J Ophthalmol 2005;15:482-5. [PubMed: 16001382]

171. Schoenfeld ER, Leske MC, Wu SY. Recent epidemiologic studies on nutrition and cataract in India, Italy and the United States. J Am Coll Nutr 1993;12:521-6. [PubMed: 8263267]

172. Schorr U, Blaschke K, Turan S, et al. Relationship between angiotensinogen, leptin and blood pressure levels in young normotensive men. J Hypertens 1998;16:1475-80. [PubMed: 9814618] 
173. Seddon JM, Cote J, Davis N, et al. Progression of age-related macular degeneration: association with body mass index, waist circumference, and waist-hip ratio. Arch Ophthalmol 2003;121:78592. [PubMed: 12796248]

174. Sheard NF. Moderate changes in weight and physical activity can prevent or delay the development of type 2 diabetes mellitus in susceptible individuals. Nutr Rev 2003;61:76-9. [PubMed: 12674441]

175. Shiose Y. Intraocular pressure: new perspectives. Surv Ophthalmol 1990;34:413-35. [PubMed: 2194306]

176. Shiose $Y$. The aging effect on intraocular pressure in an apparently normal population. Arch Ophthalmol 1984;102:883-7. [PubMed: 6732570]

177. Shiose Y, Kawase Y. A new approach to stratified normal intraocular pressure in a general population. Am J Ophthalmol 1986;101:714-21. [PubMed: 3717257]

178. Sierra-Honigmann MR, Nath AK, Murakami C, et al. Biological action of leptin as an angiogenic factor. Science 1998;281:1683-6. [PubMed: 9733517]

179. Silha JV, Krsek M, Sucharda P, et al. Angiogenic factors are elevated in overweight and obese individuals. Int J Obes (Lond) 2005;29:1308-14. [PubMed: 15953938]

180. Sjöström CD, Lissner L, Sjöström L. Relationships between changes in body composition and changes in cardiovascular risk factors: the SOS Intervention Study. Swedish Obese Subjects. Obes Res 1997;5:519-30. [PubMed: 9449135]

181. Sjöström CD, Lissner L, Wedel H, et al. Reduction in incidence of diabetes, hypertension and lipid disturbances after intentional weight loss induced by bariatric surgery: the SOS Intervention Study. Obes Res 1999;7:477-84. [PubMed: 10509605]

182. Sjöström L, Lindroos AK, Peltonen M, et al. Lifestyle, diabetes, and cardiovascular risk factors 10 years after bariatric surgery. N Engl J Med 2004;351:2683-93. [PubMed: 15616203]

183. Smith W, Assink J, Klein R, et al. Risk factors for age-related macular degeneration: Pooled findings from three continents. Ophthalmology 2001;108:697-704. [PubMed: 11297486]

184. Smith W, Mitchell P, Leeder SR, et al. Plasma fibrinogen levels, other cardiovascular risk factors, and age-related maculopathy: the Blue Mountains Eye Study. Arch Ophthalmol 1998;116:583-7. [PubMed: 9596493]

185. Sommer A. Intraocular pressure and glaucoma. Am J Ophthalmol 1989;107:186-8. [PubMed: 2913813]

186. Spaide RF, Armstrong D, Browne R. Continuing medical education review: choroidal neovascularization in age-related macular degeneration--what is the cause? Retina 2003;23:595614. [PubMed: 14574243]

187. Spector A. Oxidative stress-induced cataract: mechanism of action. FASEB J 1995;9:1173-82. [PubMed: 7672510]

188. Spector A, Garner WH. Hydrogen peroxide and human cataract. Exp Eye Res 1981;33:673-81. [PubMed: 7318962]

189. Spector A, Wang GM, Wang RR. The prevention of cataract caused by oxidative stress in cultured rat lenses. II. Early effects of photochemical stress and recovery. Exp Eye Res 1993;57:659-67. [PubMed: 8150019]

190. Spector A, Wang GM, Wang RR, et al. A brief photochemically induced oxidative insult causes irreversible lens damage and cataract. II. Mechanism of action. Exp Eye Res 1995;60:483-93. [PubMed: 7615014]

191. Stevens VJ, Obarzanek E, Cook NR, et al. Long-term weight loss and changes in blood pressure: results of the Trials of Hypertension Prevention, phase II. Ann Intern Med 2001;134:1-11. [PubMed: 11187414]

192. Stratton IM, Kohner EM, Aldington SJ, et al. UKPDS 50: risk factors for incidence and progression of retinopathy in Type II diabetes over 6 years from diagnosis. Diabetologia 2001;44:156-63. [PubMed: 11270671]

193. Su DH, Yeo KT. Diabetic retinopathy and serum lipids. Singapore Med J 2000;41:295-7. [PubMed: 11109348]

194. Suter PM, Locher R, Hasler E, et al. Is there a role for the ob gene product leptin in essential hypertension? Am J Hypertens 1998;11:1305-11. [PubMed: 9832173] 
195. Tamburrino MB, McGinnis RA. Anorexia nervosa. A review. Panminerva Med 2002;44:301-11. [PubMed: 12434112]

196. Tapp RJ, Shaw JE, Harper CA, et al. The prevalence of and factors associated with diabetic retinopathy in the Australian population. Diabetes Care 2003;26:1731-7. [PubMed: 12766102]

197. Tavani A, Negri E, La Vecchia C. Selected diseases and risk of cataract in women. A case-control study from northern Italy. Ann Epidemiol 1995;5:234-8. [PubMed: 7606313]

198. Taylor A. Nutritional influences on risk for cataract. Int Ophthalmol Clin 2000;40:17-49. [PubMed: 11064855]

199. Teuscher AU, Meienberg O. Ischaemic oculomotor nerve palsy. Clinical features and vascular risk factors in 23 patients. J Neurol 1985;232:144-9. [PubMed: 4031956]

200. Tielsch JM, Katz J, Sommer A, et al. Hypertension, perfusion pressure, and primary open-angle glaucoma. A population-based assessment. Arch Ophthalmol 1995;113:216-21. [PubMed: 7864755]

201. Torgerson JS, Hauptman J, Boldrin MN, et al. XENical in the prevention of diabetes in obese subjects (XENDOS) study: a randomized study of orlistat as an adjunct to lifestyle changes for the prevention of type 2 diabetes in obese patients. Diabetes Care 2004;27:155-61. [PubMed: 14693982]

202. Tuomilehto J, Lindström J, Eriksson JG, et al. Prevention of type 2 diabetes mellitus by changes in lifestyle among subjects with impaired glucose tolerance. N Engl J Med 2001;344:1343-50. [PubMed: 11333990]

203. Uckaya G, Ozata M, Bayraktar Z, et al. Diabetes Care 2000;23:371-6. [PubMed: 10868868]

204. Uckaya G, Ozata M, Sonmez A, et al. Is leptin associated with hypertensive retinopathy? J Clin Endocrinol Metab 2000;85:683-7. [PubMed: 10690876]

205. Ughade SN, Zodpey SP, Khanolkar VA. Risk factors for cataract: a case control study. Indian J Ophthalmol 1998;46:221-7. [PubMed: 10218305]

206. Valle V, Martos R, Gascon F, et al. Low-grade systemic inflammation, hypoadiponectinemia and a high concentration of leptin are present in very young obese children, and correlate with metabolic syndrome. Diabetes Metab 2005;31:55-62. [PubMed: 15803114]

207. van Leiden HA, Dekker JM, Moll AC, et al. Blood pressure, lipids, and obesity are associated with retinopathy: the hoorn study. Diabetes Care 2002;25:1320-5. [PubMed: 12145228]

208. van Leiden HA, Dekker JM, Moll AC, et al. Risk factors for incident retinopathy in a diabetic and nondiabetic population: the Hoorn study. Arch Ophthalmol 2003;121:245-51. [PubMed: 12583792]

209. Visser M, Bouter LM, McQuillan GM, et al. Elevated C-reactive protein levels in overweight and obese adults. JAMA 1999;282:2131-5. [PubMed: 10591334]

210. Wachter A, Sun Y, Dasch B, et al. Münster age- and retina study (MARS). Association between risk factors for arteriosclerosis and age-related macular degeneration. Ophthalmologe 2004;101:503. [PubMed: 14872268]

211. Weintraub JM, Willett WC, Rosner B, et al. A prospective study of the relationship between body mass index and cataract extraction among US women and men. Int J Obes Relat Metab Disord 2002;26:1588-95. [PubMed: 12461675]

212. West SK, Valmadrid CT. Epidemiology of risk factors for age-related cataract. Surv Ophthalmol 1995;39:323-34. [PubMed: 7725232]

213. Wong TY, Duncan BB, Golden SH, et al. Associations between the metabolic syndrome and retinal microvascular signs: the Atherosclerosis Risk In Communities study. Invest Ophthalmol Vis Sci 2004;45:2949-54. [PubMed: 15326106]

214. Wong TY, Larsen EK, Klein R, et al. Cardiovascular risk factors for retinal vein occlusion and arteriolar emboli: the Atherosclerosis Risk in Communities \& Cardiovascular Health studies. Ophthalmology 2005;112:540-7. [PubMed: 15808241]

215. Wong TY, Mitchell P. Hypertensive retinopathy. N Engl J Med 2004;351:2310-7. [PubMed: 15564546]

216. Wood PD, Stefanick ML, Dreon DM, et al. Changes in plasma lipids and lipoproteins in overweight men during weight loss through dieting as compared with exercise. N Engl J Med 1988;319:11739. [PubMed: 3173455] 
217. Wormald R, Evans J, Smeeth L, et al. Photodynamic therapy for neovascular age-related macular degeneration. Cochrane Database Syst Rev 2005;4:CD002030. [PubMed: 16235294]

218. Wu SY, Leske MC. Associations with intraocular pressure in the Barbados Eye Study. Archives of Ophthalmology 1997;115:1572-6. [PubMed: 9400792]

219. Yamagishi S, Amano S, Inagaki Y, et al. Pigment epithelium-derived factor inhibits leptin-induced angiogenesis by suppressing vascular endothelial growth factor gene expression through antioxidative properties. Microvasc Res 2003;65:186-90. [PubMed: 12711260]

220. Yilmaz MI, Sonmez A, Acikel C, et al. Adiponectin may play a part in the pathogenesis of diabetic retinopathy. Eur J Endocrinol 2004;151:135-40. [PubMed: 15248834]

221. Yoshida M, Ishikawa M, Kokaze A, et al. Association of life-style with intraocular pressure in middle-aged and older Japanese residents. Jpn J Ophthalmol 2003;47:191-8. [PubMed: 12738554]

222. Younan C, Mitchell P, Cumming R, et al. Cardiovascular disease, vascular risk factors and the incidence of cataract and cataract surgery: the Blue Mountains Eye Study. Ophthalmic Epidemiol 2003;10:227-40. [PubMed: 14628965]

223. Yudkin JS, Eringa E, Stehouwer CD. "Vasocrine" signalling from perivascular fat: a mechanism linking insulin resistance to vascular disease. Lancet 2127;365:1817-20. [PubMed: 15910955]

224. Zanella MT, Kohlmann O, Ribeiro AB. Treatment of obesity hypertension and diabetes syndrome. Hypertension 2001;38:705-8. [PubMed: 11566961]

225. Zang EA, Wynder EL. The association between body mass index and the relative frequencies of diseases in a sample of hospitalized patients. Nutr Cancer 1994;21:247-61. [PubMed: 8072878]

226. Zarbin MA. Current concepts in the pathogenesis of age-related macular degeneration. Arch Ophthalmol 2004;122:598-614. [PubMed: 15078679]

227. Zhang F, Chen Y, Heiman M, et al. Leptin: structure, function and biology. Vitam Horm 2005;71:345-72. [PubMed: 16112274]

228. Zhang L, Krzentowski G, Albert A, et al. Risk of developing retinopathy in Diabetes Control and Complications Trial type 1 diabetic patients with good or poor metabolic control. Diabetes Care 2001;24:1275-9. [PubMed: 11423515]

229. Zhou L, Li Y, Yue BY. Oxidative stress affects cytoskeletal structure and cell-matrix interactions in cells from an ocular tissue: the trabecular meshwork. J Cell Physiol 1999;180:182-9. [PubMed: 10395288] 


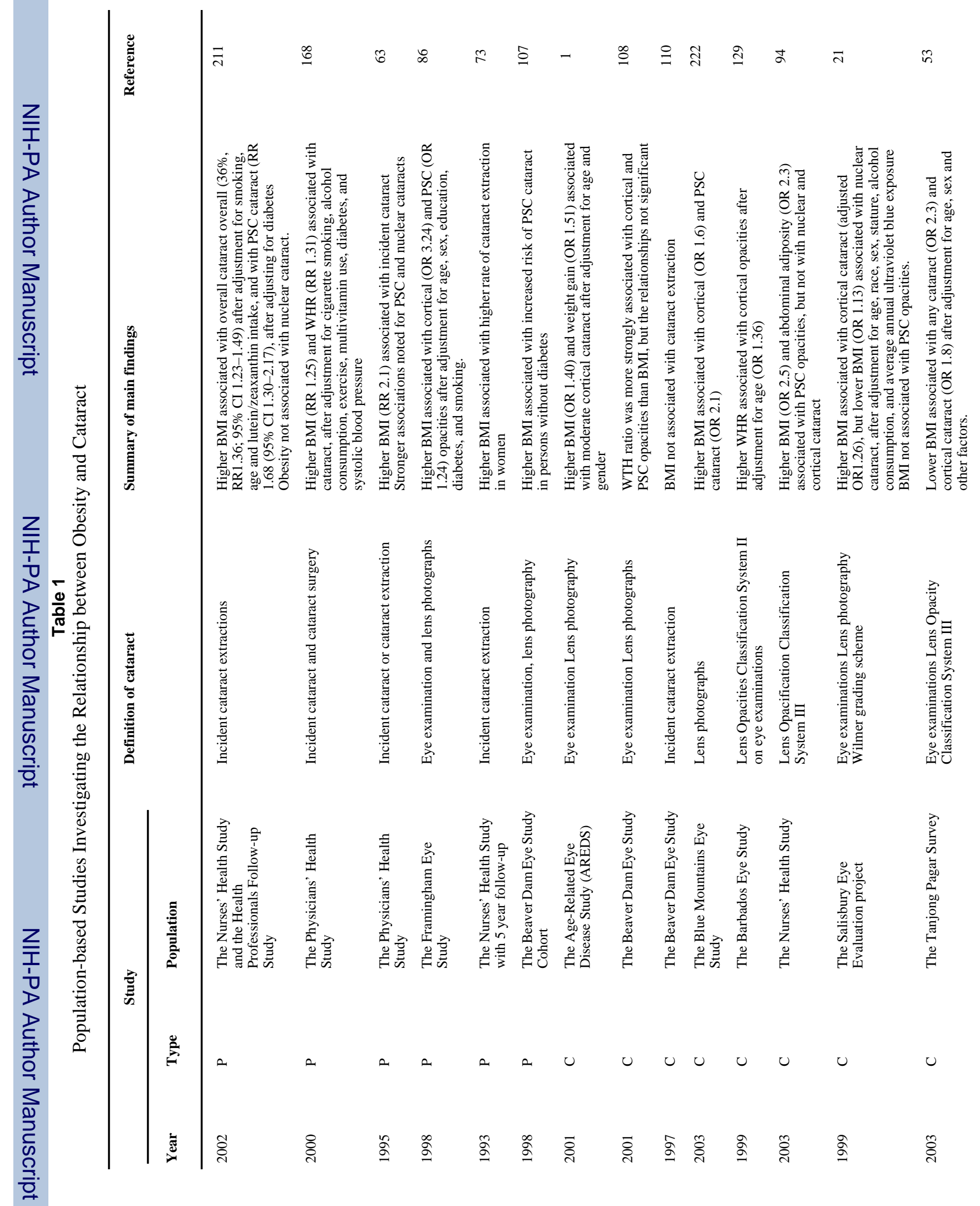




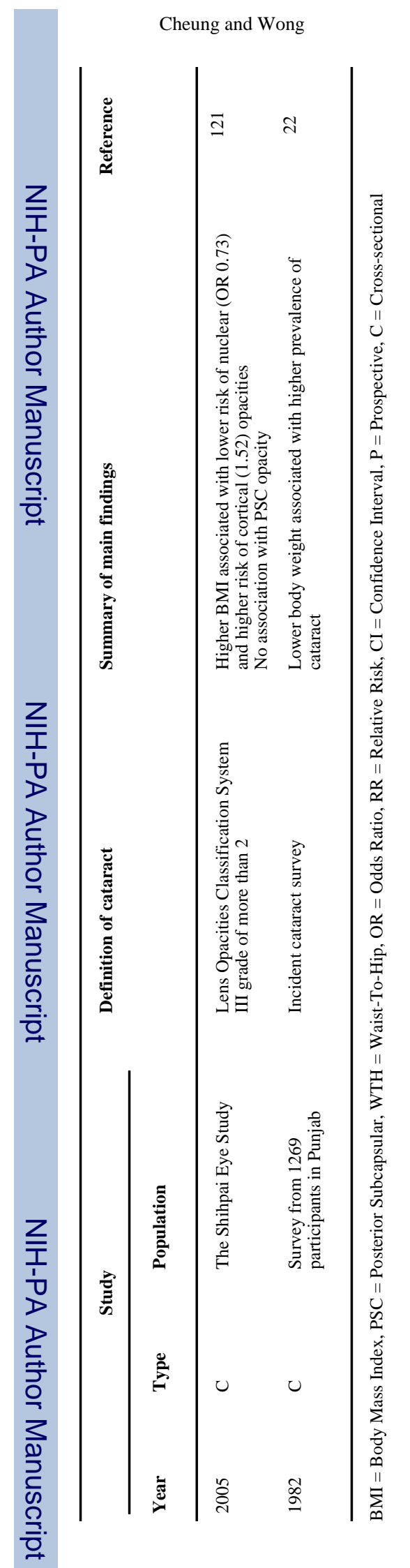

Page 21 


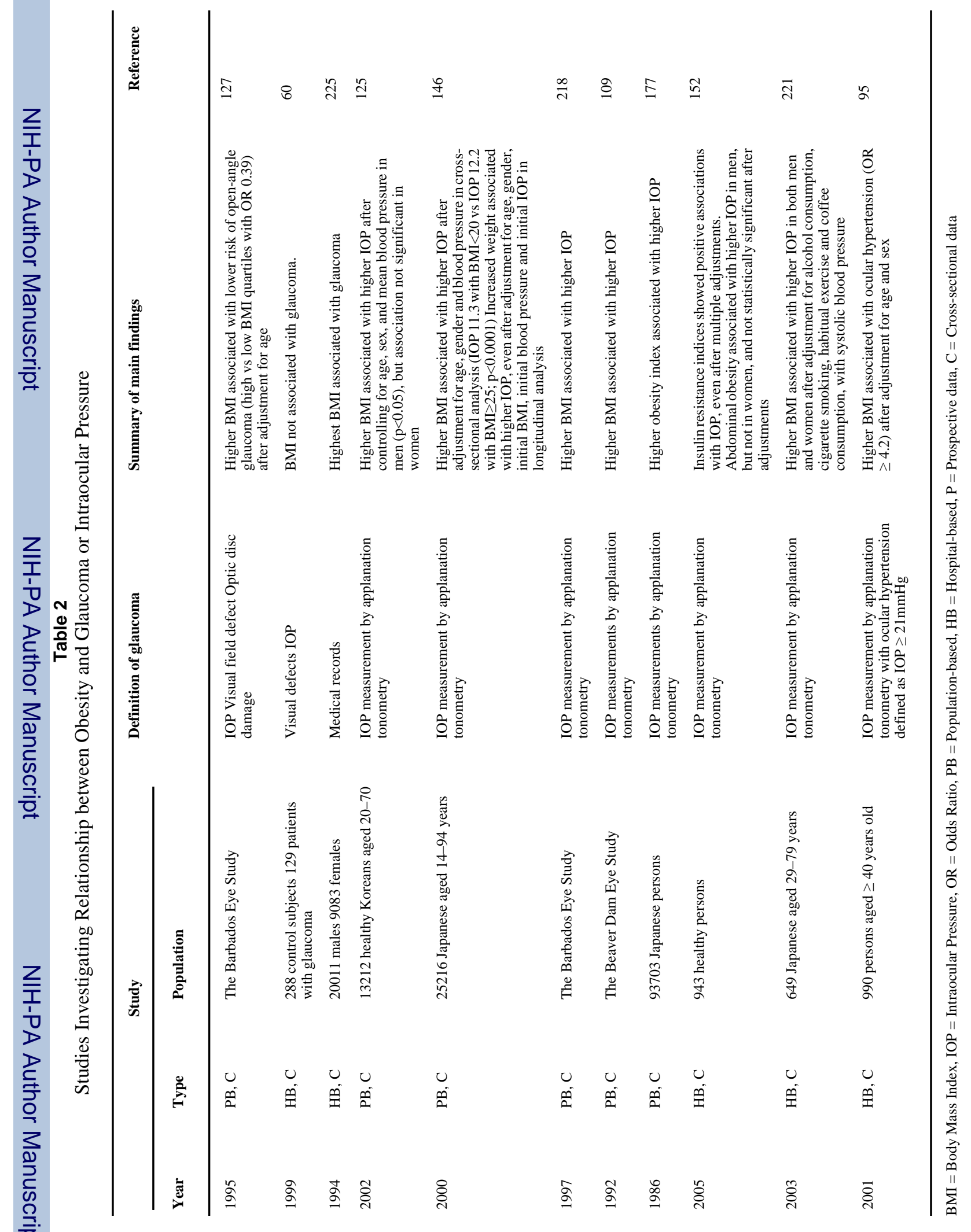




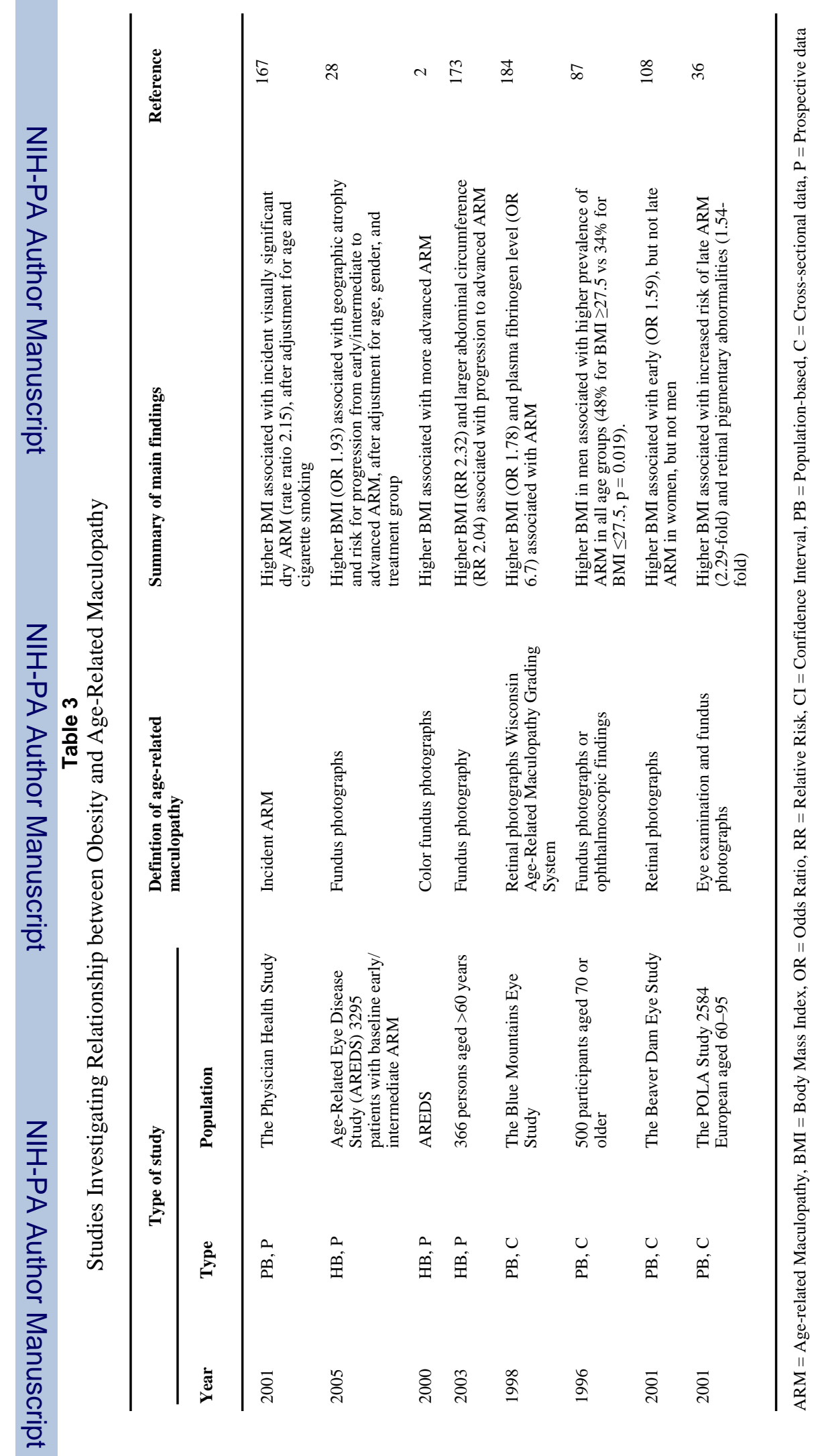




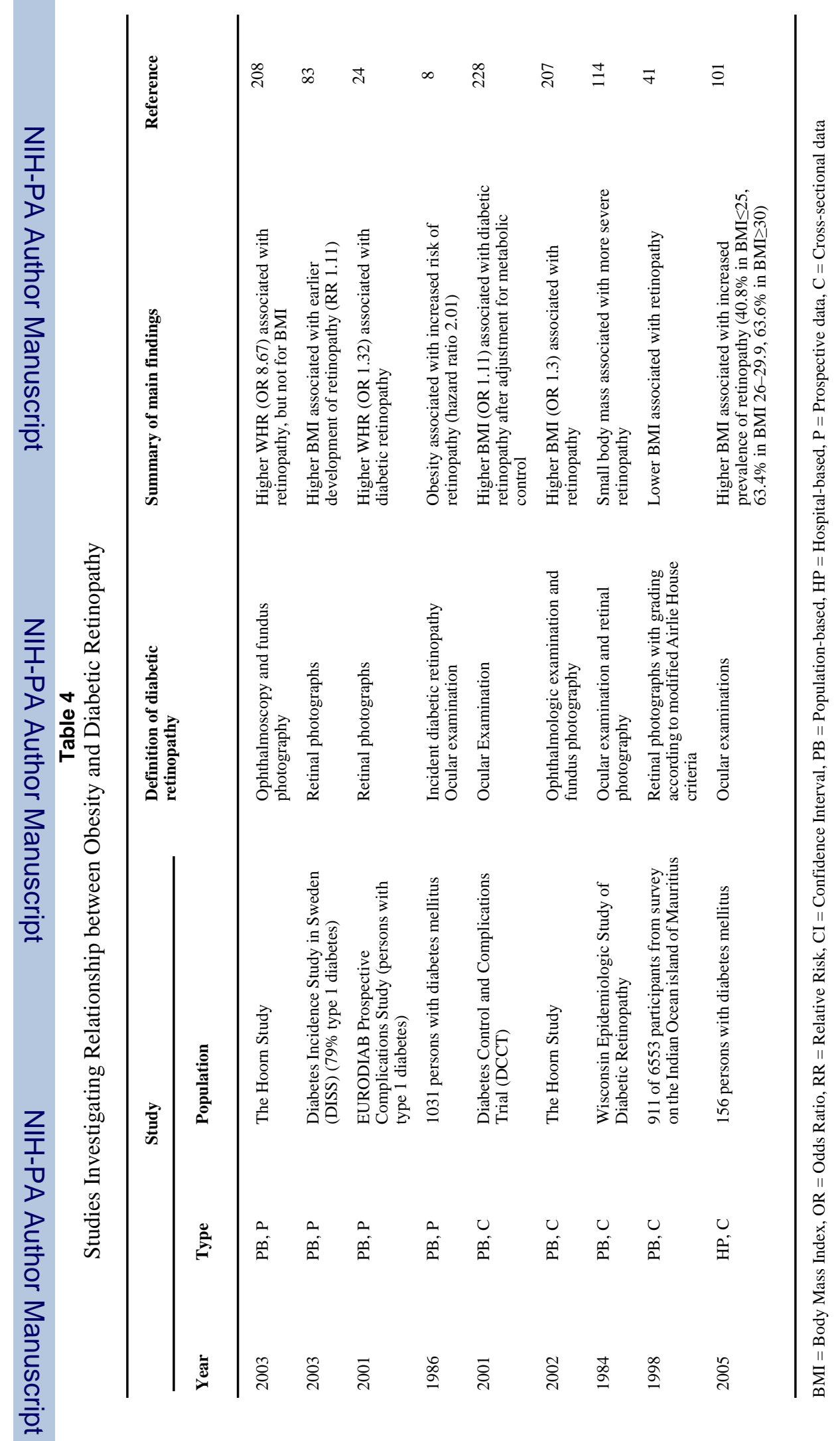

